\title{
Respiratory problems 2 years after acute bronchiolitis in infancy
}

\author{
R L HENRY, I G C HODGES, A D MILNER, AND G M STOKES \\ University Department of Child Health, University Hospital, Queen's Medical Centre, Nottingham NG7 $2 U H$
}

SUMMARY We assessed the clinical progress of 55 children 2 years after admission to hospital with acute bronchiolitis and performed lung function tests on 40. During the 2 year follow up period $75 \%$ of the children had wheezed, $36 \%$ had 2 or more lower respiratory symptoms lasting more than 2 weeks, $33 \%$ had more than 100 days of lower respiratory symptoms, and $13 \%$ were readmitted to hospital with acute respiratory disease. In addition $60 \%$ of the children were hyperinflated on lung function tests. Many of the children with hyperinflation at the 2 year assessment had not been hyperinflated 1 year earlier, suggesting variable airways obstruction. Reversibility of airways obstruction was also assessed by response to nebulised salbutamol. Nine children had a fall $>15 \%$ in airways resistance after salbutamol and these children had the highest baseline airways resistances. Airways resistance was higher in the children with a family history of atopy.

Although children often wheeze for some years after acute viral bronchiolitis, the exact relation between bronchiolitis and asthma is unclear. ${ }^{1-4}$ Evidence is also accumulating that bronchiolitis may sow the seeds for chronic obstructive lung disease in adult life $^{4-6}$ and furthermore asymptomatic children may have abnormalities in lung function many years after an attack, ${ }^{7}$ leaving the possibility that clinical illness will develop subsequently.

We have been collecting information on lung function and symptoms after the acute episode in a cohort of children admitted to hospital with acute bronchiolitis. Our first report on 22 of these infants, all of whom had severe initial disease, showed marked disturbances in lung function in the first year after the acute illness. ${ }^{8}$ We were concerned that these children might not be representative as all were fed via a nasogastric tube and we therefore collected further data on a larger group of children whose only criterion for inclusion was that they had been admitted to hospital with bronchiolitis. The results of the total cohort showed that at follow up after 1 year over $60 \%$ had had further wheezing and that $17 \%$ had marked hyperinflation on lung function tests. ${ }^{9}$ We aimed to obtain sequential information on children whose progress in the first year after bronchiolitis had been studied ${ }^{9}$ and to report on clinical progress and lung function a year later.

\section{Patients and methods}

All 55 children included in this study were admitted to hospital during an epidemic of infection caused by respiratory syncytial virus (RSV). They had a clinical diagnosis of bronchiolitis with tachypnoea, breathlessness, hyperinflation, and widespread crepitations. Viral studies were positive for RSV in 27 patients and adenovirus type 1 was isolated in 1 patient.

The first 24 children studied had severe disease and were fed by a nasogastric tube but our only selection criterion subsequently was that the children had been admitted to hospital for bronchiolitis. Nevertheless, milder cases of acute viral bronchiolitis are probably under represented in the cohort.

Mean age on admission was 96 days (range 29-335 days), and there were 26 boys and 29 girls. Twenty of the children had a first degree relative with asthma, eczema, or hay fever and of these, 9 had a first degree relative with asthma. When information on second degree relatives was included, the numbers rose to 31 and 16 respectively. These figures are comparable with unselected controls. ${ }^{2}$

Two years after the first admission to hospital we obtained histories regarding the nature, frequency, and duration of lower respiratory tract illnesses after the bronchiolitis. Fifty one of these 55 children had been seen and assessed 1 year earlier. ${ }^{9}$ 
Lung function tests were performed on $\mathbf{4 0}$ of the children on average 25 months after the initial admission (range 23-26 months). Thirty five of these children had been tested 1 year earlier. We measured thoracic gas volumes (TGV), ${ }^{10}$ the amount of gas in the lungs at the end of a normal expiration, airways resistance (Raw) using plethysmography, ${ }^{8}$ and total respiratory resistance $\left(R_{t}\right)$ by forced oscillation. ${ }^{11}$ The total body plethysmograph was a perspex construction of 2601 capacity with a servocontrolled heating system to maintain the face mask, shutter system, and rebreathing bag at $36^{\circ} \mathrm{C}$.

Each child after sedation with $100 \mathrm{mg} / \mathrm{kg}$ chloral hydrate was nursed supine, and a mask was applied to the face. A bias flow of air, $51 /$ minute, passed through the wall of the plethysmograph to the face mask via a wide bore tube, and expiratory gases were conducted out via a similar tube. Signals were relayed to the axes of a cathode ray storage oscilloscope. Measurements of Raw were obtained from the initial part of inspiration when flow is essentially laminar, rather than at $2 / 3$ of maximal inspiratory flow which in these children is under turbulent conditions and will produce much higher values. Readings were obtained and calculations made by standard techniques. ${ }^{8}$ Multiple breaths were sampled in each case.

Total respiratory resistances during inspiration $\left(R_{t}\right.$ insp) and expiration $\left(R_{t} \exp \right)$ were measured using a modification of the forced oscillation technique. ${ }^{11}$ A pressure manometer connected to the inflated flange of the face mask ensured that the mask was applied to the face with the same amount of pressure during each measurement of $R_{t} \cdot{ }^{12}$

After baseline recordings were obtained of TGV, Raw, and $R_{t}$, each child was given $2 \mathrm{ml}$ of a solution containing $5 \mathrm{mg}$ salbutamol through a Sandoz nebuliser driven by compressed air at a flow rate of $6 \mathrm{l} /$ minute. Ten minutes later TGV, Raw, and $R_{t}$ were measured again.

Statistical analysis employed Student's $t$ test and $\chi^{2}$ analysis. Our coefficient of variation for $R_{t}$ is $8.9 \% .11$ We calculated the coefficient of variation for TGV and Raw by comparing lung function before and after nebulised water in 18 children. The values were $8.0 \%$ and $15.8 \%$ respectively. The local ethical committee approved the study and informed parental consent was obtained for all tests.

\section{Results}

The frequency of lower respiratory tract symptoms experienced by the 55 children in the 2 years after their initial admissions with bronchiolitis is shown in Table 1. Cough rather than wheeze was the predominant symptom in many children with lower
Table 1 Incidence of reported lower respiratory symptoms in 55 children during the 2 years after the initial attack of brochiolitis

\begin{tabular}{|c|c|c|c|c|c|c|}
\hline & \multicolumn{2}{|c|}{$\begin{array}{l}\text { Positive } \\
\text { No }(\%)\end{array}$} & \multicolumn{2}{|c|}{$\begin{array}{l}\text { Negative } \\
\text { No }(\%)\end{array}$} & \multicolumn{2}{|c|}{$\begin{array}{l}\text { Unclear } \\
\text { No }(\%)\end{array}$} \\
\hline $\begin{array}{l}\text { Any episode of wheezing } \\
\text { Two or more episodes } \\
\text { of cough or wheeze, or } \\
\text { both, lasting more than } \\
2 \text { weeks }\end{array}$ & $\begin{array}{l}41 \\
20\end{array}$ & $\begin{array}{l}(75 \%) \\
(36 \%)\end{array}$ & $\begin{array}{l}11 \\
31\end{array}$ & $\begin{array}{l}(20 \%) \\
(56 \%)\end{array}$ & $\begin{array}{l}3 \\
4\end{array}$ & $\begin{array}{l}(5 \%) \\
(7 \%)\end{array}$ \\
\hline $\begin{array}{l}\text { More than } 100 \text { days of } \\
\text { cough or wheeze, or both }\end{array}$ & 18 & $(33 \%)$ & 32 & $(58 \%)$ & 5 & $(9 \%)$ \\
\hline $\begin{array}{l}\text { Readmission to hospital } \\
\text { with lower respiratory } \\
\text { illness }\end{array}$ & 7 & $(13 \%)$ & 48 & $(87 \%)$ & 0 & $(0 \%)$ \\
\hline $\begin{array}{l}\text { Lower respiratory illness } \\
\text { lasting more than } 2 \text { weeks } \\
\text { or any episode of wheeze, } \\
\text { or both }\end{array}$ & 45 & $(82 \%)$ & 8 & $(15 \%)$ & 2 & $(4 \%)$ \\
\hline
\end{tabular}

Table 2 Lung function data on 40 children before and after nebulised salbutamol

\begin{tabular}{|c|c|c|c|c|}
\hline \multirow[b]{2}{*}{$\begin{array}{l}\text { TGV (ml/kg) } \\
\text { TGV (\% predicted for weight) } 14 \\
\text { TGV (\% predicted for length) } \\
\operatorname{Raw}^{14}\left(\mathrm{cmH} \mathrm{H}_{2} \mathrm{O} / 1 / \mathrm{s}\right) \\
\mathrm{R}_{\mathrm{t}} \text { insp }\left(\mathrm{cmH}_{2} \mathrm{O} / 1 / \mathrm{s}\right) \\
\mathrm{R}_{\mathrm{t}} \exp \left(\mathrm{cmH} \mathrm{H}_{2} \mathrm{O} / \mathrm{l} / \mathrm{s}\right)\end{array}$} & \multicolumn{2}{|c|}{$\begin{array}{l}\text { Initial } \\
\text { (mean }(S D))\end{array}$} & \multicolumn{2}{|c|}{$\begin{array}{l}\text { After salbutamol } \\
\text { (mean SD)) }\end{array}$} \\
\hline & $\begin{array}{l}33 \cdot 9 \\
125 \\
125 \\
9 \cdot 9 \\
47 \cdot 7 \\
50 \cdot 3\end{array}$ & $\begin{array}{l}(5 \cdot 9) \\
(21) \\
(19) \\
(5 \cdot 2) \\
(21 \cdot 5) \\
(21 \cdot 5)\end{array}$ & $\begin{array}{l}32 \cdot 5 \\
120 \\
118 \\
9 \cdot 9 \\
46 \cdot 2 \\
50 \cdot 7\end{array}$ & $\begin{array}{l}(5 \cdot 9) \\
(21) \\
(18) \\
(5 \cdot 3) \\
(29 \cdot 0) \\
(33 \cdot 7)\end{array}$ \\
\hline
\end{tabular}

TGV = thoracic gas volume; $R a w=$ airways resistance; $R_{t}$ insp =tota respiratory resistance during inspiration; $R t$ exp $=$ total respiratory resistance during expiration.

respiratory disease lasting more than 2 weeks. Fifteen children had fewer reported respiratory problems in the second year of follow up, compared with the first, 17 had more, and 23 were essentially unchanged. We found no notable relation between a family history of asthma or of other atopy and the prevalence of symptoms. Height and weight percentiles of the 55 children were within normal limits. ${ }^{13}$

Lung function data on the $\mathbf{4 0}$ children tested are documented in Table 2. Thirty five of these 40 children had been tested 1 year earlier. Analysis of the sequential data shows minor changes in both TGV and Raw for the group as a whole. Thoracic gas volume fell from mean (SD) $35.4(9.9) \mathrm{ml} / \mathrm{kg}$ to $34.0(5.9) \mathrm{ml} / \mathrm{kg}$ and Raw fell from $11.3(7.5)$ $\mathrm{cmH}_{2} \mathrm{O} / 1 / \mathrm{s}$ to $9.9(5.3) \mathrm{cmH}_{2} \mathrm{O} / 1 / \mathrm{s}$. We noted considerable variations, however, in Raw and TGV in some children. Twenty two children had a TGV greater than $120 \%$ predicted for weight ${ }^{14}$ at 2 year follow up but only 11 of these $(50 \%)$ had a TGV greater than $120 \%$ predicted 1 year earlier, and 6 of the 11 children with a Raw greater than 10.0 at 2 year follow up had had a similar Raw previously.

We also assessed the reversibility of airways 
Table 3 Airways resistance in children with and without a family history of atopy (mean (SD))

\begin{tabular}{|c|c|c|c|c|c|}
\hline & No & $\begin{array}{l}\text { Present } \\
\text { Raw } \\
\left(\mathrm{cmH} \mathrm{H}_{2} \mathrm{O} /\right. \\
l / s)\end{array}$ & No & $\begin{array}{l}\text { Absent } \\
\text { Raw } \\
\left(\mathrm{cmH}_{2} \mathrm{O} /\right. \\
l / s)\end{array}$ & $\begin{array}{l}P \\
\text { value }\end{array}$ \\
\hline $\begin{array}{l}\text { Asthma in 1st degree } \\
\text { relative }\end{array}$ & 7 & $13 \cdot 2(8 \cdot 8)$ & 33 & $9 \cdot 2(4 \cdot 0)$ & NS \\
\hline $\begin{array}{l}\text { Atopy in 1st degree } \\
\text { relative }\end{array}$ & 15 & $12 \cdot 1 \quad(6 \cdot 3)$ & 25 & $8 \cdot 5(4 \cdot 1)$ & $<.05$ \\
\hline $\begin{array}{l}\text { Asthma in } 1 \text { st or } 2 \text { nd } \\
\text { degree relative }\end{array}$ & 10 & $12.8(7 \cdot 6)$ & 30 & $8.9(3.9)$ & $<.05$ \\
\hline $\begin{array}{l}\text { Atopy in } 1 \text { st or } 2 \text { nd } \\
\text { degree relative }\end{array}$ & 22 & $11 \cdot 6(5 \cdot 9)$ & 18 & $7 \cdot 8 \quad(3 \cdot 2)$ & $<.05$ \\
\hline
\end{tabular}

obstruction by means of nebulised salbutamol (Table 2). For the group as a whole we found a small decrease in TGV from mean (SD) 33.9 (5.9) $\mathrm{ml} / \mathrm{kg}$ to $32.5(5.9) \mathrm{ml} / \mathrm{kg}(\mathrm{P}<\cdot 01)$ but no significant changes in Raw or $\mathbf{R}_{\mathrm{t}}$. Nine children responded to salbutamol with a fall in Raw of more than $15 \%$. These children had higher initial airways resistances than those who did not respond. Five of the 7 highest values for Raw were obtained from children who had a response to salbutamol $(\mathrm{P}<0.01)$. Four children, 3 of whom had an initial TGV greater than $120 \%$ predicted, had a fall in TGV of greater than $15 \%$.

Higher airways resistances were found in children with a family history of atopy (Table 3). Each of the lower respiratory tract symptoms documented were individually more likely to occur in children with either higher baseline airways resistances or a $15 \%$ fall in Raw after salbutamol. These associations did not, however, reach statistical significance.

\section{Discussion}

As is shown in Table 1, further lower respiratory tract symptoms were observed in at least $82 \%$ of our children who had been admitted to hospital with bronchiolitis 2 years previously. These symptoms were often prolonged and severe, sometimes leading to hospital admission. Although none of the children were re-admitted to hospital in the second study year compared with 7 in the first year of follow up, there was little other evidence of general improvement in respiratory symptoms and 17 children were undoubtedly worse. These findings are in conflict with the conclusion drawn by Sims et al. that 'the wheezing episodes experienced subsequently by the children who had had bronchiolitis were neither severe nor frequent enough to have resulted in hospital outpatient or in-patient referral' ${ }^{15}$ One explanation for this may be that in long term retrospective studies the passage of time has blurred the memories of problems experienced in the first few years after bronchiolitis. At the 2 year assessment in our study some parents had only a sketchy recall of respiratory problems that had occurred in the first year of life. The studies which have reported that most children are clinically well 8-10 years after the initial illness ${ }^{215}$ overlook the considerable morbidity caused by respiratory disease that we have found in the first years after bronchiolitis.

Another possible explanation for the optimistic outlook given by Sims et al. ${ }^{15}$ is that their report focused on the frequency of wheezing rather than lower respiratory tract disease in general. In our study, however, wheeze was not responsible for all the respiratory problems and many children had prolonged episodes of cough as their primary symptom. Mok and Simpson have reported that 'tendency to cough' was a symptom in $34.5 \%$ of 200 children some time in the first 7 years after bronchiolitis and that $3.5 \%$ had 'established bronchitis'. ${ }^{16}$

Two years after admission to hospital with acute bronchiolitis, hyperinflation on lung function testing was common. Considerable variations were observed in some children when we compared TGV, $R_{t}$, and Raw results 2 years after admission with those obtained when the children were younger. We believe that these changes are real and not caused by technical problems. Our techniques are standardised and one of us has participated in all of the more than 250 lung function studies we have performed on the cohort of children. The logical reason for the changes in lung function is variable airways obstruction. This is supported by the correlation between high Raw and response to salbutamol. Many children, however, remain hyperinflated after nebulised salbutamol-a finding also observed by Lenney and Milner in asthmatic children of similar ages. ${ }^{11}$ They were able to show a fall in Raw of greater than $18 \%$ in 6 of 7 children over the age of 20 months, but although these children were hyperinflated, only 1 had a fall in TGV of greater than $15 \%$ after salbutamol treatment. The fact that we have been able to show the reversibility of hyperinflation in the longer term, but often not after salbutamol, suggests that mucosal oedema and mucous plugging, rather than just muscle spasm, may be important in these children. No attempt was made to postpone lung function tests until 6 weeks after a respiratory illness had resolved and some of the changes may reflect transient after effects of viral infections. ${ }^{17}$

A family history of atopy was associated with increased airways resistance but the study design did not allow a definitive statement on the relation between atopy, post-bronchiolitic wheezing, and asthma. Nor can we state how many of the lung function abnormalities we documented are reversible given more time and further lung development. 
Comparisons with other reports on children who have been symptom free for a prolonged period ${ }^{2} 7$ make it probable that some of the defects are permanent. We are following this cohort of children to try to resolve this question.

We thank the parents and the consultants, Professor D Hull, Drs P Barbor, D Johnston, and N Rutter who allowed us to study patients under their care. We also thank the Asthma Research Council and Nestle Paediatric Travelling Fellowship (Australia) for their financial support.

\section{References}

1 Rooney JC, Williams HE. The relationship between proved viral bronchiolitis and subsequent wheezing. $J$ Pediatr 1971 ;79:744-7.

2 Pullan CR, Hey EN. Wheezing, asthma and pulmonary dysfunction 10 years after infection with respiratory syncytial virus in infancy. Br Med $J$ 1982;284:1665-9.

3 Laing I, Riedel F, Yap PL, Simpson H. Atopy predisposing to acute bronchiolitis during an epidemic of respiratory syncytial virus. $\mathrm{Br} M e d \mathrm{~J}$ 1982;284:1070-2.

4 Kattan M. Long-term sequelae of respiratory illness in infancy and childhood. Pediatr Clin North Am 1979;26: 525-35.

5 Colley JRT, Douglas JWB, Reid DD. Respiratory disease in young adults: influence of early childhood lower respiratory tract illness, social class, air pollution and smoking. $\mathrm{Br}$ Med J 1973 ;iii:195-8.

- Burrows B, Knudson RJ, Lebowitz MD. The relationship of childhood respiratory illness to adult obstructive airway disease. Am Rev Respir Dis 1977;115:751-60.

7 Kattan M, Keens TG, Lapierre J, Levison H, Bryan AC, Reilly BJ. Pulmonary function abnormalities in symptomfree children after bronchiolitis. J Pediatr 1977;59:683-8.
8 Stokes GM, Milner AD, Hodges IGC, Groggins RC. Lung function abnormalities after acute bronchiolitis. J Pediatr $1981 ; 98: 871-4$.

9 Henry RL, Milner AD, Stokes GM, Hodges IGC, Groggins RC. Lung function after acute bronchiolitis. Arch Dis Child 1983;58:60-3.

10 Dubois AB, Botelho SY, Bedell GN, Marshall R, Comroe JH, Jr. A rapid plethysmographic method for measuring thoracic gas volume: a comparison with a nitrogen washout method for measuring functional residual capacity in normal subjects. $J$ Clin Invest 1956; $35: 322-6$.

11 Lenney W, Milner AD. At what age do bronchodilator drugs work? Arch Dis Child 1978;53:532-5.

12 Hodges IGC, Groggins RC, Milner AD, Stokes GM. Bronchodilator effect of inhaled ipratropium bromide in wheezy toddlers. Arch Dis Child $1981 ; 56: 729-32$.

13 Tanner JM, ed. Modern trends in paediatrics. London: Butterworth, 1958.

14 Hatch DJ, Taylor BW. Thoracic gas volume in early childhood. Arch Dis Child 1976;51:859-64.

15 Sims DG, Downham MAPS, Gardner PS, Webb JKG, Weightman D. Study of 8-year-old children with a history of respiratory syncytial virus bronchiolitis in infancy. $\mathrm{Br}$ Med J 1978;i:11-4.

16 Mok JYQ, Simpson $H$. Outcome of acute lower respiratory tract infection in infants: preliminary report of seven year follow-up study. $\mathrm{Br} \mathrm{Med} J$ 1982;285:333-7.

17 Empey DW, Laitinen LA, Jacobs L, Gold WM, Nadel JA Mechanisms of bronchial hyperreactivity in normal subjects after upper resiratory tract infection. Am Rev Respir Dis 1976;113:131-9.

Correspondence to Professor A D Milner, Department ôे फ Child Health, University Hospital, Queen's Medical Centres. Nottingham NG7 2UH.

Received 26 May 1983 